\title{
Os Alunos do Ensino Médio e Sciences Po: Entre a Meritocracia e a Percepção das Desigualdades*
}

\author{
Marco Oberti ${ }^{1}$ \\ Agathe Voisin ${ }^{2}$ \\ ${ }^{1}$ Professor do Departamento de Sociologia, Sciences Po, Paris. E-mail: \\ marco.oberti@sciences-po.fr \\ ${ }^{2}$ Doutoranda no Observatoire Sociologique du Changement, Sciences Po, Paris. E-mail: \\ agathe.voisin(at)sciences-po.org
}

\section{INTRODUÇÃO}

$\mathrm{D}$

esde o início dos anos 2000, as principais grandes escolas superiores francesas, dando continuidade às Convenções de Educação Prioritária (Conventions Education Prioritaire - CEP), propuseram ações em colégios menos favorecidos para diversificar as novas matrículas. Essas ações não são todas idênticas e nem sempre têm o mesmo fim. Se a maioria delas foi implementada para estimular, acompanhar e preparar os (melhores) alunos para o concurso de acesso, são poucas as que organizaram os requisitos de seleção e ofereceram acessos paralelos (derrogatórios) para o concurso regular. A especificidade de Sciences Po é conciliar os dois elementos: os alunos participam de workshops específicos de treinamento durante a formação no colégio e seguem etapas de seleção específica.

Dentro de um processo experimental (ver Quadro 1), Sciences Po-com outros parceiros - envolveu-se num conjunto de ações planejadas em

\footnotetext{
* Este artigo foi, originariamente, apresentado no seminário "Juventude, Desigualdades e o Futuro do Rio de Janeiro", realizado na Casa de Rui Barbosa, em junho de 2011, como parte das atividades do Programa de Apoio a Núcleos de Excelência (Pronex), sediado no Instituto de Estudos Sociais e Políticos (IESP), da Universidade do Estado do Rio de Janeiro (UERJ). [A tradução do original em francês, "Les Lycéens face à Sciences Po: Entre Méritocratie et Perception d'Inégalités" é de Gilles Mayeur].
}

DADOS - Revista de Ciências Sociais, Rio de Janeiro, vol. 56, n-1, 2013, pp. 133 a 167. 
quatro colégios da região de Seine-Saint-Denis, próxima de Paris. O objetivo deste projeto é mostrar que "uma vez apoiados em experiências pedagógicas inovadoras, já operantes nestes estabelecimentos de ensino, bem como em equipes voluntárias e concedidos os meios adequados, esses colégios, localizados em áreas carentes, podem compor contextos escolares de qualidade, capazes de assegurar o sucesso escolar em percursos e expectativas diversos". Portanto o ingresso em Sciences Po não representa a única finalidade e trata-se não apenas de criar estabelecimentos "de excelência", mas principalmente de garantir qualidade e diversidade de percurso escolar, respeitando a seleção local.

No primeiro caso (CEP), o objetivo prioriza, de fato, a diversificação da elite. A ideia é de que ao agirem antecipadamente junto aos meios menos representados e mais distantes da excelência escolar, dão-se assim as condições que corrigem os conhecidos efeitos das desigualdades sociais e regionais. Nas Grandes Escolas Superiores, lugares por excelência de formação da elite, faz-se necessário atuar na seleção para diversificá-la. No segundo caso, a ambição está mais relacionada com o objetivo de "igualdade de oportunidades" envolvendo a escolaridade num sentido mais amplo, além da possibilidade de conseguir uma formação de qualidade e assim melhores oportunidades de acesso ao emprego, sem, no entanto, a obrigação de passar pelas Grandes Escolas e fazer parte da elite. Em ambos os casos, além de romper com a lógica regional de nichos, caracterizada por dispositivos tipo ZEP (Zona de Educação Prioritária), trata-se principalmente de impulsionar as ações e os meios concedidos.

Os dois objetivos, diversidade da elite/igualdade de oportunidades, não são necessariamente contraditórios e, tampouco são sempre congruentes. É perfeitamente possível atuar no primeiro objetivo, sem por isso consolidar mais amplamente a igualdade de oportunidades, ou melhor, combater de forma mais abrangente as desigualdades. Eles também não envolvem os mesmos meios. As comparações internacionais baseadas nas pesquisas PISA (Programme International pour le Suivi des Acquis) [Programa Internacional de Avaliação de Alunos] evidenciam duas especificidades marcantes do sistema escolar francês: uma grande diferença no desempenho escolar entre uma elite bem dotada e a grande massa dos alunos; assim como a influência significativa do meio social e cultural no sucesso escolar (Baudelot e Establet, 2009). Os programas de Sciences Po não fogem desse dado estrutural: o CEP va- 


\section{Quadro 1}

\section{Os Dispositivos Sciences Po}

\section{O Programa Experimental}

Através de um conjunto de ações planejadas para estabelecimentos de ensino, o programa experimental determina como objetivo "valorizar, ampliar e perenizar o sucesso em colégios públicos, setorizados, em bairros menos favorecidos", por meio de três princípios básicos:

- O aluno, "ator" de sua formação

O enfoque é colocado na motivação ("levar os alunos até o melhor de si") e no acompanhamento individual dos alunos. Informação e orientação são prioridades. Cada aluno é dotado de um referencial/adulto que o acompanha nos vários aspectos da escolaridade. Os alunos beneficiam-se de avaliações sobre sua competência ao longo do ano. O trabalho em pequenos grupos é valorizado. Um acompanhamento escolar é oferecido fora do período letivo, especialmente durante as férias.

- Organização do tempo e formatos de ensino implementados a partir das necessidades dos alunos

São incentivadas a variedade dos métodos pedagógicos além da pluridisciplinaridade. As aulas são dadas a duas ou três vozes. Semanalmente, a metade de um dia de estudos é dedicada a um projeto desenvolvido ao longo do ano, reunindo professores de várias disciplinas e envolvendo frequentemente uma dimensão artística. Esse trabalho é realizado em grupo (exemplo: montagem de peça teatral, realização de vídeos por meio de telefone celular).

- Um colégio inserido num território e aberto para o mundo

Articulações com o ensino superior, bem como com empresas da região onde os alunos realizam estágios, são estimuladas. Diversos encontros e debates são promovidos com profissionais de vários setores. Os alunos são sensibilizados ao debate social, ético e político. Os programas culturais são numerosos (teatro, ópera...). A abertura para o mundo se concretiza também através de viagens com destinos inéditos para os alunos: China, Cuba, Senegal, Nova York...

O programa experimental tem por vocação englobar as ações dos estabelecimentos de ensino em seu conjunto, através da criação de "colégios pilotos", e funciona atualmente na base do voluntariado das equipes de docentes, que abrem "turmas experimentais" de acordo com seu envolvimento e suas possibilidades. Assim, uma mesma turma do primeiro ano do ensino médio pode receber ensinamentos experimentais de uma parte da equipe pedagógica e um ensinamento tradicional da outra parte da equipe; já outras turmas da escola permanecem totalmente fora do programa. As primeiras classes experimentais contavam com 500 alunos do primeiro ano do ensino médio, em quatro colégios de Seine-Saint-Denis, no início do ano letivo de 2006. Desde então, foram ampliadas para outros níveis e outros estabelecimentos.

Para mais detalhes: http:/ /www.sciences-po.fr/press/lycee/Projet-cadreãetablissement.pdf. 


\section{Quadro 1}

Os Dispositivos Sciences Po (continuação)

\section{As Convenções de Educação Prioritária}

Trata-se de uma ferramenta de abertura social de Sciences Po. Assim, são elas apresentadas no site desta Escola Superior na internet: o objetivo é desfazer o "bloqueio social" e "restabelecer a igualdade de oportunidades" combatendo quatro desvantagens dos alunos da ZEP (Zona de Educação Prioritária): falta de recursos financeiros, ausência de informação especializada, viés social nas provas de seleção e situação de autocensura.

\section{- As Oficinas de Sciences Po:}

Hoje existem 62 colégios conveniados. Qualquer colégio localizado no território nacional pode firmar uma convenção, desde que atenda aos critérios da política de educação prioritária conduzida pelo Estado. Os estabelecimentos de ensino conveniados, baseados no voluntariado dos professores, promovem "oficinas Sciences Po" semanais, onde os alunos ganham preparo para as provas de admissão. Durante estas oficinas, são disponibilizadas informações sobre o ensino superior bem como é estimulada a motivação para estudos seletivos. Os alunos são sensibilizados para o debate social e político. Além da preparação para Sciences Po propriamente dita, os alunos encontram também um acompanhamento pessoal e aulas de apoio em algumas matérias. Ao longo do ano, é organizado um intercâmbio entre os colégios parceiros e Sciences Po (como eventos nessa Escola Superior dirigidos aos alunos, incluindo a simulação anual de um Conselho de Segurança da ONU).

- As provas de admissão:

A admissibilidade é delegada aos diretores dos estabelecimentos e aos professores dos colégios. Durante a primavera do último ano do ensino médio, os alunos apresentam de forma autônoma, uma análise sobre matérias publicadas na imprensa relativas ao trimestre anterior. Também é levada em conta a avaliação escolar. Em seguida, os candidatos capacitados à admissão, devem ser aprovados no Vestibular que ocorre no mês de junho, para se apresentarem ao exame oral de admissão em Sciences Po. Este exame é uma entrevista com duração de 30 a 40 minutos, diante de uma banca composta por cinco personalidades (docentes de universidades, altos funcionários do setor público, diretores de empresas privadas, professores e membros da Diretoria de Sciences Po e personalidades convidadas).

- Os aprovados:

447 alunos ingressaram em Sciences Po através do Programa CEP, desde sua criação em 2001. Foram 17 no primeiro ano e 118 em 2008 (ou seja, 15,9\% dos candidatos). Dentre eles, de $50 \%$ a $70 \%$ são filhos de desempregados, trabalhadores ou funcionários; $75 \%$ são bolsistas e 2/3 tem ao menos o pai ou a mãe nascido fora da França.

Para mais detalhes: http://www.sciences-po.fr/formation/inscriptions/cep. html\#0cep.html\#0

lida uma distinção já estabelecida entre os canais de elite e o restante (mesmo em se tratando de diversificar a seleção); em contrapartida, o programa experimental tenderia a melhorar mais amplamente a eficiência do sistema escolar. 
Além desta diferença pouco percebida pelos alunos e menos ainda pelos pais, essas ações fazem parte de uma espécie de "requalificação escolar", que adota a referência e a mobilização de uma Grande Escola Superior dentro de estabelecimentos carentes e até estigmatizados. Novas aspirações e perspectivas surgem e reconfiguram contextos locais estruturados pela exclusão escolar e urbana. Estes mecanismos criam adaptações, tensões que percorrem uma relação elementar, às vezes mais fatalista diante da escolaridade e do futuro social. Ocasionalmente, a mobilização de uma Escola prestigiosa não tem apenas efeitos sobre a escolaridade num sentido restrito, mas age também sobre a imagem e a atratividade do estabelecimento de ensino em questão. O modo pelo qual os alunos dos colégios e seus pais ${ }^{1}$ constroem uma relação com o bairro e a escola envolve uma série de interações que remete a representações, negociações e tensões que precisam ser apreendidas. Como instituição e contexto de interação, a Escola tende, sobretudo, a impor seus princípios e o sentido que dá a suas ações. Porém, os alunos os reinterpretam e introduzem dimensões práticas e simbólicas, que concernem a outras experiências e referências, das quais o bairro constitui um elemento importante. É importante que se compreenda as reinterpretações e distorções que daí possam nascer para abarcar o que produzem tais iniciativas nos bairros e colégios populares.

\section{VÁRIAS HIPÓTESES NORTEARAM ESTE PROCESSO}

Em primeiro lugar, o contexto urbano, o pertencimento à classe popular, assim como a origem estrangeira apresentam três determinantes sociais ou estruturais que enquadram de forma desigual, com efeitos variáveis e estatisticamente identificáveis, as práticas escolares dessas famílias numa relação de distância ou de relativo afastamento à instituição. Na realidade e particularmente neste caso, estes contextos locais e escolares mesclam, de forma acentuada e visível, as dimensões sociais (pertencimento às categorias populares e mesmo precárias) e "étnicas" (origem estrangeira, experiência migratória, ambiente cultural e linguístico, estigmatização), compostas pela presença significativa de camadas populares de imigrantes ou de origem imigrada. No âmbito escolar, mecanismos clássicos de distanciamento/desprovimento encontram-se reconfigurados e até amplificados pela própria referência a excelência escolar francesa representada pelas ações de Sciences Po. Assim, o modo pelo qual os alunos vão se referir à instituição escolar e ainda a seu funcionamento, princípios, veredictos e às 
oportunidades oferecidas, se compreende também em relação ao modo no qual os pais se encontram desprovidos.

No entanto, os determinantes sociais mencionados acima, não poderiam ser determinismos absolutos através dos quais se reproduziria, nos alunos, o afastamento de seus pais da escola e que finalmente levariam a um "fracasso" das ações de Sciences Po junto aos alunos dos colégios. Há uma certa reapropriação ou uma reelaboração dessas ações com múltiplos efeitos ligados à percepção de um "eu colegial" e de seus ambientes (sociais, urbanos, escolares etc.). A maioria dos alunos de origem popular destes bairros (frequentemente advindos da imigração) é obrigada a construir-se de forma antecipada, porém incerta, como "sujeitos" ou "atores" da própria "experiência escolar" ${ }^{2}$. O relacionamento desigual entre o acompanhamento escolar e os dispositivos Sciences Po gera, em alguns pais, um "crédito de confiança" à instituição, mas principalmente aos filhos (os alunos). Uma ampla maioria deles, desprovida das conivências implícitas compartilhadas entre os que são essencialmente franceses e que cresceram neste sistema, "confiam" nos filhos para escolher entre os canais de ensino, avaliar o próprio nível, a apreciação dos professores e para se projetar em estudos superiores. Então, a capacidade do aluno em construir com relativa autonomia sua trajetória é fundamental e quase sempre interpretada externamente como "qualidade" (motivação, desejo de sucesso, persistência, desembaraço etc.) que os dispositivos Sciences Po procuram reconhecer e valorizar.

Sob este ponto de vista, mais do que os outros alunos, de meios sociais mais favorecidos e que são apoiados e acompanhados na escolaridade, estes alunos dos colégios ZEP, majoritariamente de origem popular, são duplamente responsabilizados: por seus pais que, aliás, neles confiam e deles esperam "êxito", e por ações do tipo Sciences Po, que se apoiam precisamente em supostas "qualidades" entre as quais autonomia, motivação, etc. Nós nos deteremos particularmente em ressaltar o impacto de tais ações que centralizam os alunos, não somente como "beneficiários", mas também como "responsáveis" de seu investimento, escolha e futuro. Os esforços dispensados por vários alunos estão à altura das expectativas vividas antes de se entrar numa Grande Escola, mas refletem um profundo ressentimento quando a esperança não se concretiza. Em ambos os casos, essa experiência transforma sua visão da meritocracia e das disparidades. 
Como os alunos percebem esses programas que visam atuar no contexto escolar em parcerias com instituições prestigiosas? Essas ações fazem parte de uma mudança de postura diante da escola, da meritocracia, da percepção das desigualdades e das discriminações no seio da sociedade francesa? Como são percebidas e interpretadas pelos alunos? São elas fontes de novas tensões?

Tentaremos responder a essas perguntas a partir de uma pesquisa de múltiplas abordagens (análise dos contextos urbanos e escolares locais, questionários e entrevistas com pais de alunos, entrevistas coletivas com alunos, observação etnográfica de longa duração), realizada entre 2006 e 2008, em quatro colégios da região de Seine-Saint-Denis envolvidos nos dispositivos de Sciences Po (CEP + Programa Experimental), concentrando-nos na análise das entrevistas coletivas realizadas com os alunos (Quadro 2).

\section{Quadro 2}

Realização de entrevistas coletivas com alunos nivelados por grupos (primeiro, segundo e terceiro ano do ensino médio) em três estabelecimentos de ensino nos anos de 2007 / 2008. Esses grupos reuniam em média 4 a 15 alunos em função das turmas e se juntaram de 3 a 5 vezes durante o ano, para sessões que duravam entre uma e duas horas e meia. No total, 60 alunos participaram dessas turmas ( 13 do primeiro ano do ensino médio, 24 do segundo e 23 do terceiro ano). Nessas sessões, eram discutidas a relação dos alunos com a escolaridade (orientação, projetos de estudo, notas e aprendizagem), a vida colegial (vida escolar e disciplina, relacionamentos entre alunos e entre as diversas categorias do pessoal do estabelecimento) e os dispositivos Sciences $\mathrm{Po}$, dos quais uma ampla maioria dos alunos questionados participavam. Finalmente, um eixo urbano sobre a relação com o bairro, as instituições e os distúrbios de rua de 2005, objetivava entender a forma pela qual os alunos articulavam as questões de desigualdade, injustiça e discriminação entre os contextos escolar e urbano. Algumas entrevistas individuais foram desenvolvidas mais adiante com antigos alunos que ingressaram ou não em Sciences Po.

\section{CONTEXTOS LOCAIS}

A pesquisa é relacionada a quatro colégios situados em municípios populares do nordeste parisiense, envolvidos em programas de parceria com Sciences Po. Trata-se assim de contextos escolares específicos, cuja localização em áreas urbanas relegadas, com alta concentração populacional de imigrantes ou originada da imigração, é um ponto básico na sua estigmatização e seleção para implantação de programas de "discriminação positiva" provenientes de uma "Grande Escola". Esta concentração elevada de pobreza e desemprego, conjugada à ampla 
presença de famílias imigrantes, diferencia estes bairros, social e etnicamente mistos, da grande maioria dos bairros da região Île de France (Préteceille, 2006 e 2009), assim como de outras cidades francesas.

Da mesma forma, construindo um raciocínio a partir de noções tais como "municípios e colégios populares", não se trata de negar ou minimizar diferenças, às vezes muito importantes, não somente entre estes colégios e municípios, mas também dentro do mesmo município e entre os bairros. Estas discrepâncias são relevantes, tanto no que diz respeito à composição socioprofissional por parte dos imigrantes, quanto ao tecido urbano e aos estatutos de ocupação.

Contudo, essas noções compartilham algumas características comuns. Os dados da Tabela 1 mostram que estas cidades são marcadas por uma população jovem e de baixa renda, com nenhum ou poucos diplomas, e por uma presença significativa de estrangeiros, de imigrantes e de famílias numerosas. No conjunto, mais de $60 \%$ da população ativa pertence a grupos de operários ou funcionários. Cerca de um terço da população de 15 anos ou mais não possui diploma, um pouco menos da metade da população total tem menos de 30 anos, os imigrantes representam em média um terço da população e a taxa de desemprego chega a $20 \%$.

No entanto, a cidade de Clichy-sous-Bois se diferencia dos três outros municípios, com taxas quase sempre bem acima, exceto por sua população e a proporção da habitação social. Ela se destaca claramente como o município mais desfavorecido. A proporção das classes populares bem como dos imigrantes é de mais de 10 pontos acima em relação à população da cidade de Bondy, sendo a diferença até maior para os sem diploma, enquanto o percentual de famílias numerosas dobra em comparação à cidade de Saint-Ouen.

A mesma lógica se encontra em termos de estabelecimentos de ensino secundário. Em muitos aspectos, os colégios destes quatro municípios compartilham características comuns, que os destacam nitidamente dos colégios bem mais favorecidos e justificam sua classificação em ZEP e por isso mesmo, são tratados como uma categoria específica de estabelecimento. Entretanto, isto não deve minimizar as diferenças entre eles, quer se trate do perfil dos alunos, do corpo docente, da oferta e dos resultados escolares etc. (Tabela 2). 
Os Alunos do Ensino Médio e a Sciences Po: Entre a Meritocracia...

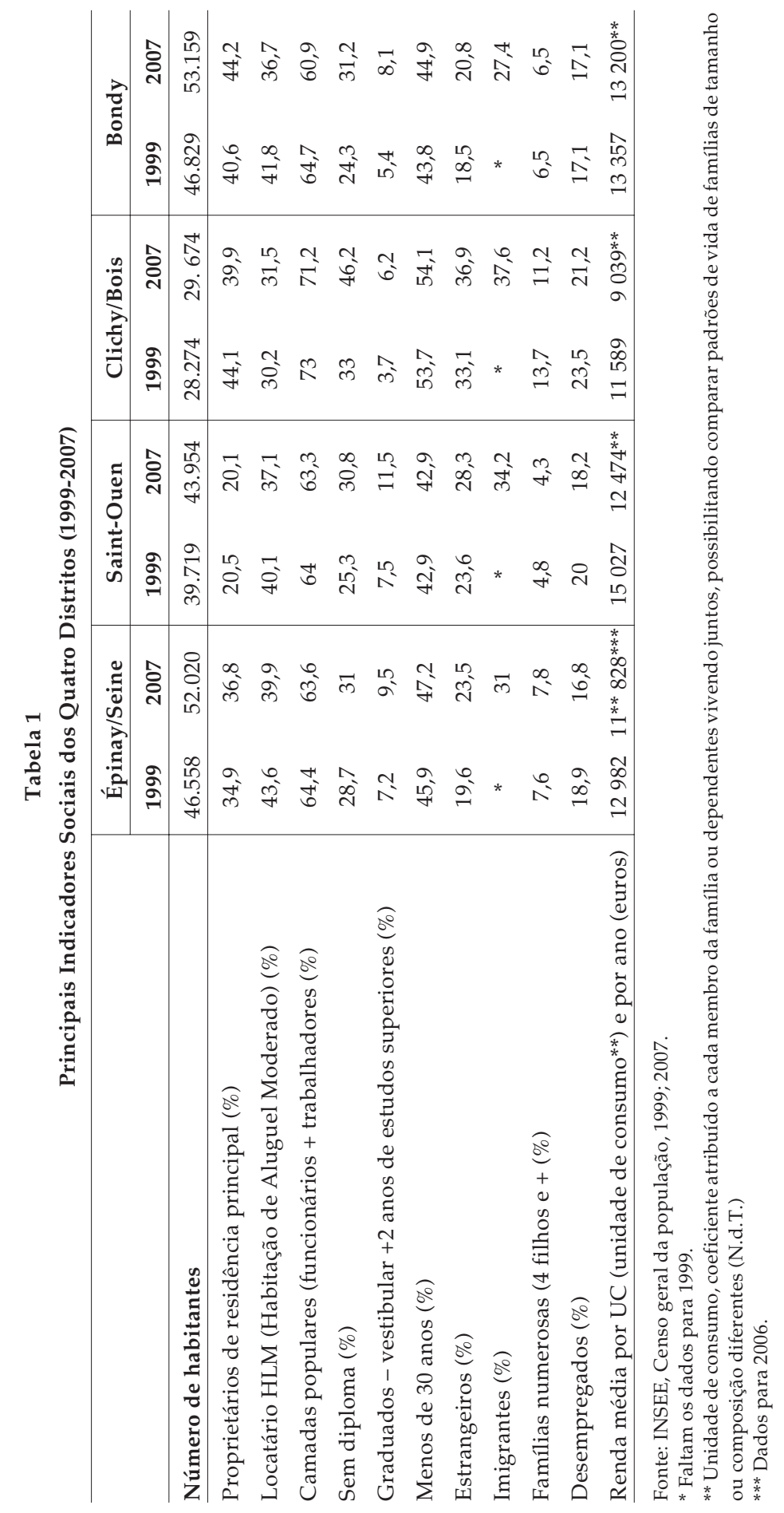

DADOS - Revista de Ciências Sociais, Rio de Janeiro, vol. 56, nº 1, 2013 
Marco Oberti e Agathe Voisin

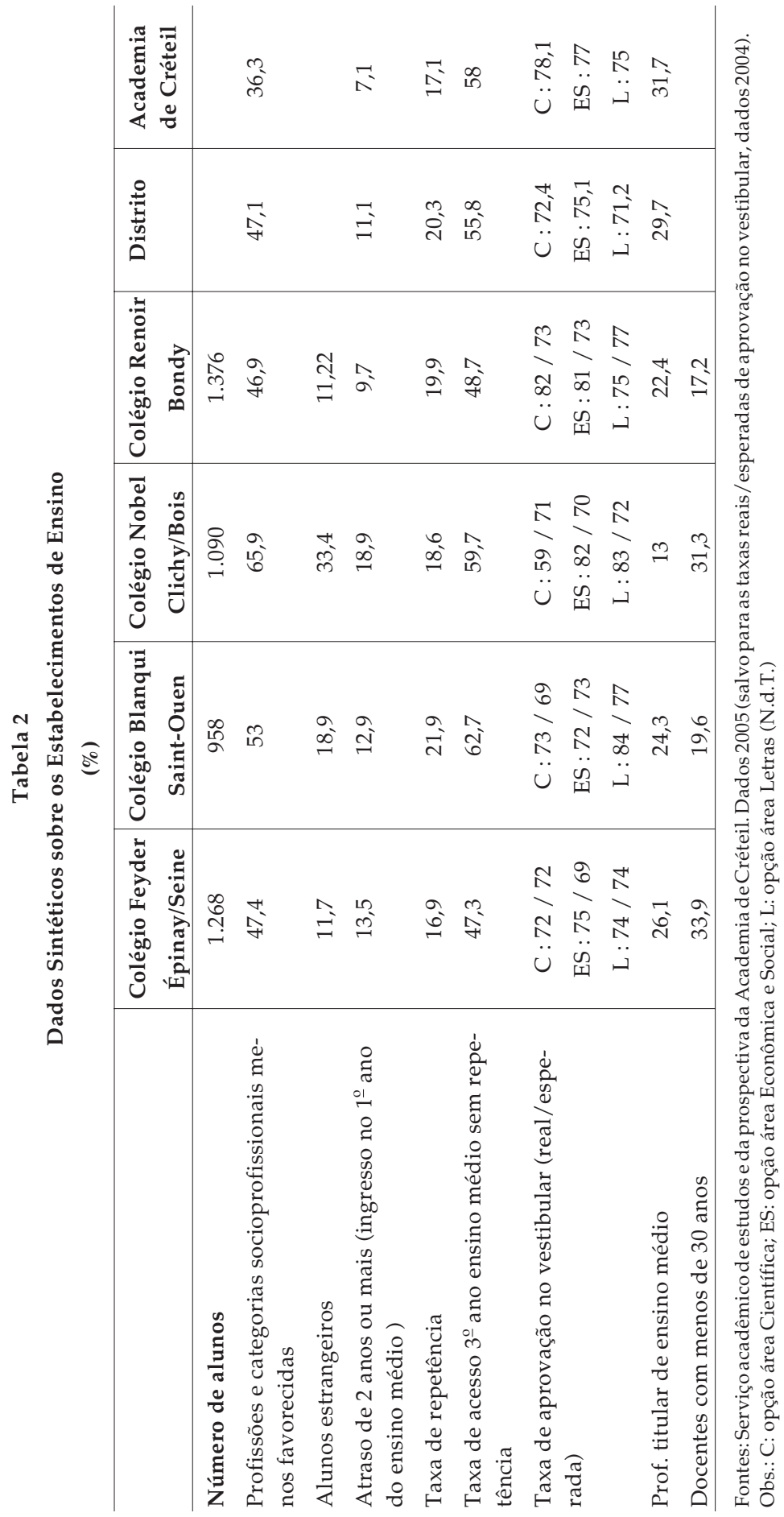


A pesquisa, por meio de questionário junto aos pais, possibilitou definir a origem paterna e ressalta novamente a especificidade acentuada destes estabelecimentos. Duas perguntas foram colocadas aos pais dos alunos: 1) qual é sua nacionalidade? (pai/mãe); e 2) qual é seu país de origem? (pai/mãe)

É preciso entender a palavra "origem" como uma referência estrita à origem declarada pelos pais dos alunos, sem a possibilidade de determinar a temporalidade e o conteúdo da experiência migratória e sem a necessária associação de características, especificidades e coerências de ordem étnica, cultural ou racial. No entanto, a questão sobre a origem, assim formulada, oferece uma dupla vantagem que foi revelada pelos resultados obtidos. Funciona como um proxy server, relativamente confiável, do país de nascimento, mas expõe também algo sobre a força e a permanência da origem ao definir sua identidade. Declarar um país de origem diferente daquele de nascimento é uma forma de reatar-se a esta origem, é referir-se a ela para definir sua própria identidade.

Quando são levados em consideração a nacionalidade e o país de origem expressos pelos entrevistados, nota-se sem surpresa a frequente incongruência destas duas características. São claras duas constatações: no grupo de pais de alunos questionados nos quatro colégios, vemos que, se por um lado muitos imigrantes possuem a nacionalidade francesa, por outro, a maioria destes franceses são imigrantes. Primeiramente, as mães que vêm da África subsaariana (menos o Sahel) ou da Ásia, em mais de $60 \%$ dizem possuir a nacionalidade francesa. Já nas mães do Sahel (Mali, Senegal, Mauritânia) e mais ainda da Turquia, recém-imigradas, poucas são as que têm nacionalidade francesa $(27 \% \mathrm{e}$ $17 \%$ respectivamente). As imigrantes do Magreb se encontram numa posição intermediária do ponto de vista da nacionalidade. A constatação é similar para os pais. Em segundo lugar, na amostra estudada, apenas uma minoria de mães declarando a nacionalidade francesa, indica a França metropolitana como país de origem (38\%, 37\% para os pais). Elas se dividem então em várias origens: 11,1\% para o Ultra-Mar e Haiti, 21,1\% para Algéria, Marrocos ou Tunísia, 8,6\% para a África subsaariana (exceto Sahel), 6,7\% para a Ásia, 2,7\% para a Europa e $2,4 \%$ para a África saheliana e $8 \%$ para as mães de outra origem ou desconhecida. 
Estes dados confirmam em que ponto a nacionalidade não constitui uma informação pertinente para avaliar a diversidade das origens migratórias num estabelecimento escolar ou num bairro, especialmente em tipos de configuração urbana e escolar próprios dos subúrbios populares das grandes cidades. Baseando-se na origem declarada, nota-se que a proporção dos casais com os dois cônjuges declarando origem francesa é aproximadamente $20 \%, 24 \%$ composto por casais de origem europeia (sobretudo portuguesa) e $30 \%$ se forem acrescentados casais dos quais pelo menos um membro declara a origem francesa. $\mathrm{Ou}$ seja, cerca de $70 \%$ dos alunos frequentando estes estabelecimentos, pertencem a famílias marcadas pela experiência de migração extraeuropeia e cuja cor da pele ou outros traços fenotípicos podem constituir fatores de discriminação (Ndiaye, 2008) ${ }^{3}$. Esta presença relevante de alunos imigrantes ou oriundos da imigração envolve outros estabelecimentos na região de Île de France, porém as taxas mencionadas aqui são particularmente elevadas e constituem uma característica marcante destes estabelecimentos. Contudo, a indisponibilidade de tais dados aplicados a muitos estabelecimentos não permite comparações sistemáticas.

Tabela 3

Distribuição das Origens Migratórias dos Alunos

\begin{tabular}{l|c|c}
\hline & \% & N \\
\hline França & 19,5 & 232 \\
Europa & 4,5 & 54 \\
Ásia & 6,5 & 78 \\
Sahel & 5,1 & 61 \\
Maghreb & 27,2 & 324 \\
África outras regiões & 7,6 & 91 \\
Ultra-mar e Haiti & 7,3 & 87 \\
Turquia & 4,8 & 57 \\
Misto (um francês) & 6,5 & 78 \\
Misto (ausência de francês) & 3,9 & 46 \\
Outros & 7,0 & 83 \\
\hline Total & $\mathbf{1 0 0 , 0}$ & $\mathbf{1 . 1 9 1}$ \\
\hline
\end{tabular}

Fonte: Enquete do Observatoire Sociologique du Changement - Sciences Po, 2009.

Na verdade, são nestes contextos urbanos e escolares específicos que se tornam necessários reinserir e recontextualizar as experiências dos alunos e o modo pelo qual eles as relatam. 


\section{ALUNOS DO ENSINO MÉDIO FRENTE A SCIENCES PO: ENTRE CRENÇA MERITOCRÁTICA E DESIGUALDADES}

Os dispositivos Sciences Po expõem tensões próprias da experiência colegial nestes contextos urbanos e escolares específicos. Trazem também novas tensões com efeitos às vezes paradoxais: ao mesmo tempo em que arraigam nos alunos uma profunda fé na meritocracia, a escola e as instituições republicanas propiciam, às vezes, uma tomada de consciência das desigualdades escolares bem mais afinada e amarga.

\section{Segregação, Desorientação e "Motivação" Incerta: Algumas Frágeis Experiências Colegiais}

Os dispositivos mencionados atendem às tensões específicas de experiências colegiais marcadas pela segregação urbana, certa desorientação escolar e uma difícil "motivação".

A segregação urbana é definida pela tensão acentuada entre uma estigmatização coletiva e a diversidade de experiências e trajetórias sociais dos habitantes. A carga da imagem negativa do "9-3"4, citada logo no início das entrevistas, pesa sobre os alunos ${ }^{5}$ que a pressupõem compartilhada pelos pesquisadores recém-chegados. Consequentemente, em razão das várias desventuras vividas durante pequenos trabalhos remunerados nas férias ou até com pessoas próximas, os alunos preferem muitas vezes omitir o nome desta região ou da cidade de origem. Esta estigmatização coletiva (que mescla dimensões territorial, social, étnica, etária e de gênero) é para eles mais insuportável ainda porque oculta as disparidades importantes que existem não somente entre as cidades da região, mas também dentro delas. A experiência vivenciada nas casinhas de subúrbio contrasta com a dos conjuntos habitacionais no âmbito dos modos de sociabilidade e de socialização assim como dos níveis de exposição à violência social, econômica e policial. Então, para afastar o estigma, os alunos acentuam suas diferenças. A ruptura urbana "casinhas de subúrbio/conjuntos habitacionais", torna-se um incentivo quase caricatural nas entrevistas; essa ruptura opõe o subúrbio do bem ao subúrbio "onde se faz de um tudo" (rapaz, 20 ano do segundo grau, cidade de Bondy).

Esta tensão entre destinos individuais e coletivos permanece no cerne da experiência colegial. Para alguns, a escolaridade nos colégios do bairro dá continuidade ao enclausuramento no meio social do qual, antes de tudo, eles querem escapar ("é este exatamente o lema familiar: 
fugir de Clichy, a qualquer custo", rapaz, 3o ano do segundo grau, Clichy). Superpondo uma segregação escolar à segregação urbana, a setorização duplica então o sentimento de injustiça ${ }^{6}$. Para outros, o acesso ao segundo grau e, sobretudo, aos colégios de aplicação, representa a promessa de ascensão social, uma forma de evitar a segregação.

Uma outra tensão que percorre a experiência colegial diz respeito à relação particular às escolas de famílias populares, frequentemente imigrantes, por vezes pouco familiarizados com o sistema escolar francês. Seus filhos são a primeira geração a estudarem além do ensino fundamental. Essas famílias colocam grandes expectativas na escola ${ }^{7}$, num ambiente em que o sucesso social e econômico parece ser apenas assegurado por diplomas; esse êxito dos alunos deveria também, de alguma forma, justificar o sacrifício parental da emigração/imigração. No entanto, essas expectativas tropeçam na extrema complexidade de um sistema escolar do qual as famílias não detêm as chaves. Esse sentimento de impotência dá lugar a um crédito de confiança à escola e, sobretudo, aos alunos. Diante das próprias contradições de orientação institucional ${ }^{8}$, os alunos queixam-se de uma pressão excessiva sobre os ombros. Se as trajetórias escolares de irmãos e irmãs mais velhos às vezes oferecem recursos significativos, os jovens constroem o percurso escolar num confronto relativamente exclusivo com a instituição.

Entre vontade de fuga e impressão de enclausuramento, entre fortes esperanças e sentimentos de impotência, essas tensões acentuam a dificuldade de "se motivar" ${ }^{\text {" }}$ que expressam os alunos, tanto no trabalho de aprendizagem diante do ensino que faz pouco sentido ("as categorias socioprofissionais de nada servem: quando falam que a avó não vive com você, então quer dizer que ela não faz parte da família, isso não serve para nada!" Jovem, primeiro ano do ensino médio, Bondy) e no compromisso diário necessário à atividade dos alunos, quanto no longo e até longuíssimo prazo da trajetória escolar projetada ("se eu tiver a oportunidade de continuar os estudos, vou até... a saturação", garota, último ano do ensino médio, Bondy). Essa "motivação" bastante abstrata $^{10}$, que os alunos perseguem e que custam a manter, cede lugar, em muitos deles, à desmotivação, à desistência da competição e a uma confiança ambígua em relação à instituição ${ }^{11}$.

Diante dessas tensões que fazem a fragilidade específica da experiência estudantil nestes contextos, os dispositivos não atuam somente nos conteúdos oferecidos, mas também nas representações, comportamen- 
tos e disposição dos jovens em relação à escola e à sociedade. As lógicas de reparação, motivação e transformação, já operando em parte nos estabelecimentos de ensino e reforçadas pelos dispositivos, não são desprovidas de contradição.

\section{Uma Super-Reparação?}

Nos ambientes escolares e urbanos menos favorecidos, muitos alunos chegam à escola com uma autoestima enfraquecida por percursos escolares dolorosos; expressam então demandas de cuidados, proteção e uma nova segurança. Uma orientação caótica ("a gente caiu numa roubada", "fomos jogados aí", frases da classe do primeiro ano do ensino médio em Bondy), que os levou pelas várias "classes lixeira" do colégio, e a violência de julgamentos escolares, às vezes associados a certo desprezo social, constroem relações com adultos e aprendizagens extremamente conflituais. Vários trabalhos mostraram atividades de "reparação" dessa frágil experiência escolar conduzida pelos estabelecimentos. Através de relações personalizadas ${ }^{12}$, adaptação do trabalho aos alunos e mobilização do estabelecimento, precisava-se reforçar as autoestimas social e escolar dos jovens e substituir a motivação deficiente (Jellab, 2005; van Zanten, 2001). De alguma forma, os dispositivos implementam uma super-reparação.

A dedicação pessoal dos professores, essencial nesses dispositivos funcionando a partir do voluntariado, é particularmente apreciada pelos alunos que descrevem "bombas de professores acionadas com gravidade para os alunos" (último ano ensino médio, Bondy). O envolvimento dos professores se manifesta tanto nas CEP, onde os alunos se beneficiam de uma supervisão semanal adicional, quanto fora da própria preparação para o concurso, que inclui aulas particulares e acompanhamento pessoal além do programa experimental, onde os professores organizam e supervisionam passeios e viagens, bem como a implantação de oficinas e tutela personalizada. Aliás, esses docentes não se incomodam em sair do ambiente puramente escolar para se mobilizar em favor da vida social dos alunos, como demonstra o engajamento de vários deles no apoio aos alunos sem visto de permanência no país e ameaçados de expulsão ("isso mostra que eles dão também muita importância à nossa vida... escolar e pessoal", último ano do ensino médio, Clichy). Essa lógica de doação/não doação envolve por sua vez os alunos que se sentem valorizados, objeto de atenção e escuta. Eles a descrevem como um motor essencial da motivação escolar. 
"Eu vi verdadeiramente a diferença entre uma classe comum e uma classe experimental. Até a relação com os professores não é a mesma de jeito nenhum, vai... além de uma relação aluno-professor, é aí... realmente que se sente a confiabilidade neles, o investimento apropriado em nós" (garota, último ano do ensino médio, Bondy).

As inovações propriamente pedagógicas destes dispositivos são dificilmente percebidas pelos alunos, para quem, frequentemente, as modalidades e princípios dessas ações permanecem obscuros ${ }^{13}$. "É certo que quando você está na experimental, 5a feira à tarde, você faz outra coisa sem relação com o programa". Assim resume essa aluna do 20 ano do ensino médio em Bondy. Além de vantagens em termo de conteúdo ou aprendizagem, os melhores alunos mencionam de antemão a "motivação" adicional que tiram de novos modos de ensino (aula a três vozes, trabalho em projetos coletivos) que quebram a monotonia dos exercícios escolares. Esses jovens, que incorporaram a lógica de reparação e mobilização no centro dos dispositivos, encaram a competição escolar principalmente nestes termos. Já os alunos mais jovens e escolarmente menos seguros ficam desestabilizados com exercícios pouco clássicos (como a realização de uma maquete em história/geografia), por formas de avaliação não tão claras e que não precisarão ser refeitos durante a escolaridade. ${ }^{14}$ "A gente não pediu nada", reclamam os alunos do primeiro ano do ensino médio em Bondy, diante do excesso de estudo e da maior carga escolar; para eles a experimentação parece um obstáculo a mais num percurso escolar já semeado de armadilhas.

Entretanto, a importância dos recursos usados (prova disso são as viagens com destinos inéditos: China, Cuba, Senegal, Nova York...) e a diversidade dos atores envolvidos (os alunos concentram a atenção de escolas superiores, grandes empresas, instituições culturais, jornalistas, políticos...) contribuem a uma dinâmica de mobilização repercutindo na imagem que os alunos fazem deles mesmos, de seu colégio e do sistema educativo. Frente a uma sociedade dominada pelas desigualdades e discriminações, a escola, sendo um estabelecimento excepcionalmente mobilizado em prol do sucesso colegial, aparece como um agente igualador de oportunidades: "igualdade de oportunidade na escola? Justamente! O colégio é prova disso: as convenções ZEP também" (garota, último ano do ensino médio, colégio Jean Renoir).

Contudo, essa "super-reparação" da qual fazem parte estes dispositivos tem efeitos potencialmente ambíguos. Ocasionalmente a ruptura entre o colégio e o ensino superior é particularmente dolorosa para alunos habituados, dizem eles, a serem "mimados"15 (primeiro ano do ensino médio, Clichy). 


\section{Efeito de Imagem e Supermotivação?}

Outra dimensão sobre a ação dos dispositivos é a mobilização dos alunos diante do futuro e da orientação com o risco de gerar neles uma supermotivação.

A informação a respeito dos estudos superiores constitui o cerne dos dispositivos. As classes experimentais oferecem uma tutela personalizada aos jovens, enquanto os CEP, fora da preparação ao IEP (Institut d'Etudes Politiques), visam melhor divulgar os canais seletivos de ensino superior e estimular um grande número de alunos a encontrarem uma orientação. Estes elegeram em massa a competição dos Ateliers Sciences Po e testemunham o modo pelo qual suas ambições cresceram ao longo do ano. Os que não foram admitidos no concurso de Sciences Po tiveram sua escolha de orientação no ensino superior definida: muitos deles se orientam para classes preparatórias ou outros canais seletivos que possibilitem acesso às escolas superiores.

Esta competição se apoia essencialmente num discurso que critica a suposta autocensura dos alunos e sustenta a realidade de oportunidades iguais e a meritocracia. Este discurso é muito eficiente junto aos jovens que não hesitam em estigmatizar a "cultura do fracasso" para expressar sua diferença (último ano do ensino médio, Bondy) dos colegas e que só querem acreditar na fórmula "quem quer consegue", repetida com insistência. Aliás, os dispositivos e a entrada efetiva de alguns dos condiscípulos numa escola prestigiosa vêm confirmar essa crença.

Sciences Po, francamente... no início eu pensava não ter capacidade ou que eu não teria nenhuma chance e finalmente, todos nós temos chance, a gente pode conseguir se tiver uma vontade verdadeira. Vamos aplaudir ou o quê? (Aplausos, risos). Parece propaganda da Adidas: "Impossible is nothing" (último ano do ensino médio, Bondy).

O avesso desse discurso é a responsabilização dos alunos, que só podem se autoculpar em caso de fracasso. Por outro lado, os CEP reforçam esta vulnerabilidade por efeito de imagem e a grande carga emocional que colocam nos alunos durante o último ano do ensino médio, já exaustivo. Pela súbita proximidade com uma instituição de elite, antes desconhecida pela maioria (em Sciences Po os alunos são convidados anualmente a realizar uma simulação de um Conselho da ONU), o tão esperado sucesso escolar e social parece subitamente a seu alcance. 
Entretanto, este sucesso permanece quase irreal e atribuído a eleitos: "é igual à lua" dizem duas alunas de Clichy.

"Você precisava ver, quando a gente voltou de Sciences Po, foi... durante dois dias, eu nem tinha dormido, nem comido. Porque é tanto isso o que eu quero fazer que eu juro que é verdade, durante dois dias eu não comi. Eu não conseguia engolir nada" (último ano no ensino médio, Bondy). "Para mim, as barreiras são o estresse que a gente tem todo dia: é possível chegar a Sciences Po? Será que não vai ser muito difícil? Vão aceitar a gente?" (segundo ano do ensino médio, Clichy).

A temática recorrente da motivação, apresentada como a chave do sucesso pessoal, é uma muralha necessária, porém frágil, diante da realidade das desigualdades escolares. Isso reflete uma tensão paradoxal no centro destes dispositivos, focados nas representações e aspirações dos alunos, onde convivem lógicas que trazem novas garantias e proteção, paralelamente a uma lógica de responsabilização dos alunos.

\section{ENTRE SOCIALIZAÇÃO CIDADÃ E CONVERSÃO IDENTITÁRIA}

Finalmente, é através da oferta de conhecimento e capacidades extraescolares (cultura geral, facilidade oral na argumentação e no debate, abertura cultural e social) - um tipo de pré-socialização aos estudos superiores - que os dispositivos buscam modificar a relação dos alunos com o trabalho escolar, as aprendizagens e mais amplamente suas representações da sociedade e do lugar que ocupam. Duas lógicas paralelas, em parte contraditórias, se opõem: uma socialização cidadã aberta para o universal e uma conversão identitária e cultural às normas dominantes.

O colégio forma futuros cidadãos: leva alunos, às vezes já maiores de idade, a abstrair-se de suas particularidades locais, familiares e culturais para ter acesso ao universal (Barrère e Martuccelli, 1998; Vitiello, 2008). Essa socialização cidadã impregna os dispositivos e especialmente as CEP: trata-se de convencer jovens, cuja cidadania é aparentemente posta em dúvida pela experiência de segregação e estigmatização de seu direito e vocação, a intervir no debate democrático, a engajar-se politicamente e participar socialmente. Nesse contexto, viagens, programas culturais e encontros com vários expositores externos, devem estimular os alunos a afastar a própria experiência pessoal e ampliar seu ponto de vista. Ocasionalmente, esse trabalho de objetivação e argumentação é bastante consciente. 
Não que isso (as injustiças) não me incomode. Tento não dar atenção. Porque como eu já disse, se dermos atenção, não progrediremos. Na perspectiva do que faço no momento (a prova oral de admissão em Sciences Po), é preciso que eu tenha pontos de vista objetivos e que eu faça comparações (rapaz, último ano do ensino médio, Clichy).

Nos alunos mais envolvidos nos dispositivos, esse trabalho é acompanhado de uma transformação das representações sociais: eles relatam a transição de uma visão exclusiva em termos discriminatórios e centrada na experiência do subúrbio ("Havia mais negros e árabes, enfim, os... aqueles de origem estrangeira e depois o resto. (...) Eu estava pra caramba nessa perspectiva. (...) Eles estão sempre contra nós - 'eles', não se sabe naturalmente quem são - estão sempre contra nós; eu tinha mania de perseguição", garota, último ano do ensino médio, Bondy), para uma visão mais extensa em termos de desigualdades sociais ("me dou conta de que não... não existem discriminações, existem fatos; e claro que é preciso combatê-los, mas não é... não é alguma coisa que é feita deliberadamente, de fato") e gerando possibilidades de mobilização, se não esquecermos a questão das discriminações, assinaladas pela diversidade das vítimas: sobretudo mulheres, homossexuais, deficientes físicos..., as formas de ação levadas em consideração são decididamente republicanas: concentradas na luta contra as desigualdades sociais, recusam qualquer lógica de discriminação positiva e mais ainda de quotas.

Em primeiro lugar, as discriminações estão ligadas à condição social. (...) Eu penso que elas vêm, antes de tudo, das desigualdades (sociais).

(...) Primeiramente é preciso atuar na nossa condição social, antes de lutar contra as discriminações. O automatismo vai se engatar e o processo que cessa as discriminações vai se engatar também (garota, último ano do ensino médio, Bondy).

A transformação das representações sociais é acompanhada de uma fé acentuada nas instituições republicanas e uma confirmação de seu lugar como cidadãos. Desde então, eles se afirmam como franceses, o que não lhes era muito evidente antes disso.

Eu confesso que no ano passado se me tivessem feito a pergunta: "você é o que?" eu teria respondido que sou de Mali. Eu não teria dito: "eu sou francesa". Enquanto meu irmão me pergunta agora: "mas você é uma o que?" Ora, eu sou uma francesa igual a você! Eu nasci na França. Sei lá... Nós somos todos franceses e o fato de estar num colégio ou em outro 
não vai mudar muita coisa, enfim (garota, segundo ano do ensino médio, Clichy).

Essa socialização cidadã, eficiente nos alunos já com uma melhor disposição face ao colégio, significa de alguma forma a última etapa da "reparação".

No âmbito pessoal, isso abriu meus olhos em relação a muitas coisas que fazem com que eu fique com mais energia e me dá mais vontade ainda de vencer. Pessoalmente, isso me "levantou", me confirmou o fato de que meu lugar era na França, eu não iria para outro lugar, eu era francesa antes de ser... de origem $x$ ou $y$. Isso me abriu os olhos para um monte de coisas, tenho ainda mais vontade de vencer, mais vontade ainda de chegar a Sciences Po para ajudar meu país que é a França e eu descobri isso graças à minha viagem ao Senegal e... ajudá-la, trabalhar no serviço público, pessoalmente é um de meus sonhos (garota, último ano do ensino médio, Bondy).

Outra lógica essencial nos dispositivos estabelece uma tensão entre essa socialização cidadã. Uma conversão cultural e identitária para as normas dominantes que determina os alunos a deixarem sua cultura popular. Fundamentalmente, o meio social e familiar dos jovens é abordado como uma "desvantagem", a chave do sucesso sendo encontrada desde que sejam afastados desse ambiente ${ }^{16}$. Assim, os passeios culturais são acompanhados de um discurso às vezes miserabilista sobre eles, o qual precisaria ser mudado, enquanto os diversos profissionais interventores nos CEP exortam os estudantes a abrir mão de certo "espírito suburbano". Se os jovens mais envolvidos nos dispositivos aceitam até certo ponto essa visão negativa deles próprios ("isso abre nossos olhos e nos mostra nossa capacidade de ter uma reflexão", último ano do ensino médio, Bondy), na qual encontram também um meio de mostrar sua diferença, eles permanecem calados diante das marcas mais violentas desse processo de aculturação forçado; por exemplo, quando o interventor, testemunhando um desconhecimento e certo menosprezo face ao meio social dos estudantes, se excede comentando um artigo para intimá-los a não assistir televisão, nem usar tênis. Essas retificações sobre modos de fazer, se vestir e falar não deixam de surpreender os alunos, tamanha a diferença em relação ao que eles esperavam da preparação escolar e da meritocracia.

Esse processo de aculturação é especialmente ambivalente e doloroso para os alunos que, ao mesmo tempo, esperam e temem essa transfor- 
mação. De certa forma, esta simboliza o sucesso escolar e a ascensão social esperada ${ }^{17}$. Em Clichy, para um aluno que perguntou incrédulo diante da empolgação dos colegas: "porque vocês pensam que tem que ir para Sciences Po, porque tem que ir pra lá?", uma outra respondeu com fé: "Para um burguês, ir pra lá não é nada. Mas para você, vai ser outra coisa, porque vai realmente mudar você". Da mesma forma, os alunos têm medo de se trair e trair o meio social do qual já estão se afastando por muitos aspectos. ${ }^{18} \mathrm{Em}$ Bondy, a turma da Oficina, antes das provas orais de admissão, se compromete com uma certa solenidade, a não mudar, não renegar seus valores.

Para mim, tem um negócio que não vai mudar: se eu for para Sciences Po, ou para a Escola Nacional de Administração (ENA), para onde você quiser, lá ou em qualquer lugar, até o recanto mais afastado dos Estados Unidos, minha forma de pensar, minha forma de ser, não vai mudar. Aperta a minha mão.

Assim, os alunos tomam a defesa de um meio social e familiar depreciados, tanto pelos dispositivos e pela escola em geral ${ }^{19}$, quanto pela mídia; a estes valores opõem-se aqueles que frequentemente receberam de uma rígida educação, bem como a riqueza de experiências adquiridas por terem crescido num meio popular. Esta defesa é tão mais acalorada, que, por várias vezes, os alunos se acham numa situação instável dentro da própria família, com quem negociam diariamente a adoção de normas de classe média, nos programas fora de casa, nos relacionamentos homem-mulher, na relação intergeracional ou até no modo de se comportar à mesa.

Eu me revolto em casa para mudar alguns pensamentos. (...) De vez em quando, me dizem que eu falo muito e... eu fico irritado, mas mesmo assim eu falo, porque eu acho que tem que ter troca, tem que ter comunicação, senão não se chega a nada (...).

Até sofro gozação dentro da minha própria família, já que eu leio muito e adoro os filmes antigos com Jean Gabin... e sempre meus irmãos riem da minha cara. O engraçado é que me chamam 'de francesa'. Ao mesmo tempo, eles tiveram que entender tudo isso e agora... eles deviam ter ido ao colégio, é isso aí (...).

Se eu uso garfo pra comer, na mesma hora dizem: você está se fazendo de francesa! Se eu cruzo as pernas - costumo fazer isso desde pequenase eu estiver aí assim toda empinada vão dizer: 'o que que você está fa- 
zendo? É uma francesa!' Realmente eles não sabem que... é um hábito sei lá. Não é... (garota, segundo ano do ensino médio, Clichy).

A violência desta dinâmica de conversão mantém ainda mais distantes os alunos mais reticentes ${ }^{20}$ em relação às transformações identitárias provenientes da escola. Na realidade, nestes contextos sociais específicos, muitos fazem uma ruptura entre o universo do bairro e o universo escolar (“É principalmente a mentalidade. Quando eu vou à escola, eu pego a velha mentalidade, saio, encontro com os amigos, se abrem as portas do infinito!" Rapaz, último ano do ensino médio, Bondy). Ruptura que, para ser mantida, necessita de um distanciamento dos dois universos, muito longe da transformação identitária esperada. Os alunos, especialmente os mais revoltados, com percursos escolares mais sofridos, escutam estes discursos como mais uma prova de menosprezo diante da qual rejeitam os dispositivos e junto com eles os valores do sistema escolar, esboçando uma crítica da dominação social.

- Eu não vejo porque você menciona Sciences Po.

- Se você for, vai dar o exemplo.

- Então, você se sente inferior.

- Mas é claro!

- Ué, mas é grave! É muito grave o que você acabou de falar (...).

- Espera aí, eles podem conseguir muito mais coisas do que... Espera aí..., eles passam as férias em Londres.

- Nunca se deve sentir inferior aos outros.

- Intelectualmente, eu não me sinto inferior aos "burgueses", enfim... - A baderna da semana passada: vários jovens do subúrbio foram falar com grandes deputados (...). Os deputados vêm de um meio burguês. Mesmo assim, tem jovens do subúrbio que falaram com eles, realmente num vocabulário (...).

- Tem pessoas que eu conheço que nem foram à escola e conhecem coisas sobre a Rússia.

- É isso aí!! Não precisa ir a Sciences Po para ter cultura (segundo ano do ensino médio, Clichy).

A visão elitista dos dispositivos, e particularmente dos CEP, se depara com uma Escola que deixou de ser uma instituição (Dubet, 2002) e onde um público popular negocia diariamente seu envolvimento na articulação entre várias classes de normas. Longe de atingir de forma homogênea uma comunidade colegial muito heterogênea, estas lógicas violentas social e simbolicamente, acentuam ainda mais as tensões, 
num meio social marcado por uma estigmatização comum e enormes desejos de diferenciação.

Paradoxalmente, os dispositivos enraízam assim nos alunos muita fé nas instituições republicanas e na escola, ao mesmo tempo em que revelam aos jovens os vieses sociais e culturais. Desta forma, conduzem-nos a uma tomada de consciência mais nítida e complexa dos processos de desigualdades.

\section{CONSCIENTIZAÇÃO DAS DESIGUALDADES ESCOLARES E SOCIAIS}

Finalmente, os processos de reparação, mobilização e transformação nos centros dos dispositivos, revelam aos alunos a dimensão das desigualdades escolares, se opondo diretamente aos princípios de meritocracia e igualdade de oportunidades que são transmitidos.

A própria presença dos dispositivos evidencia uma desvantagem da qual os alunos não tinham antes consciência ("Porque a gente tem verdadeiras dificuldades, talvez no ensino ou talvez em nós mesmos, em relação à nossa vida, somos... filhos e filhas de imigrantes, talvez seja em relação a isso", segundo ano do ensino médio, Clichy). A insistência sobre os esforços e a motivação que devem trazer, confirma o tamanho da reparação social necessária e a distância que os separa daqueles que são chamados de alunos "normais". Também é o avesso da visibilidade midiática: "a gente até sai no jornal quando alunos do colégio Jean Renoir entram em Sciences Po", constata ironicamente um aluno do segundo ano do ensino médio. Eles ficam menos irritados com as apresentações jornalísticas que focalizam o lado inesperado e excepcional do ingresso dos colegas em Sciences Po.

E a forma pela qual foi representado Ange, do jeito que falaram "um aluno de Clichy-sous-Bois en Sciences Po" é como se fosse... como se fosse um ideal, um sonho, como se fosse... inesperado (garotas do segundo ano do ensino médio, Clichy).

São esses mesmos olhares miserabilistas que os levam a denunciar o caráter ligeiramente menosprezador das ações:

Acham que a gente não viaja, não sai do nosso distrito $93 \ldots$

- A gente é ralé, né (...).

- Certamente nunca viajaram, né! (primeiro ano do ensino médio, Bondy). 
Parece um discurso um pouco miserabilista e consciência limpa. Já que nós somos uma Escola Superior, vamos nos interessar um pouquinho pelos pobres (segundo ano do ensino médio, Epinay).

Tem pessoas que pensam: o que vamos fazer com esse subúrbio? Vamos dar para eles miudezas (último ano do ensino médio, Epinay).

Para os estudantes que convivem mal com esta estigmatização do meio social, esta visibilidade da desvantagem, mesmo real, é insuportável ("atrás de tudo isso, existe a ideia de que os colégios do 93 não são iguais aos outros (...); não é errado, tudo bem, mas você não precisa mostrar isso", (último ano do ensino médio, Epinay). É o que amplamente criticam na política de educação prioritária, o que lhes parece mais uma causa de dificuldades adicionais do que uma ajuda. O selo ZEP, estigmatizante, concentra toda a amargura dos alunos que se sentem permanentemente capturados por dispositivos supostamente criados para ajudá-los. "Porque somos rotulados de imediato?" Rebela-se Milena, no segundo ano do ensino médio em Bondy.

Tem outro negócio mal feito. Porque a gente tá numa ZEP e não no Colégio Louis le Grand? Esse negócio de ZEP, eu nunca vou entender. Porque ZEP? Somos um colégio, tem alunos, só isso. É um bairro delicado, tudo bem, mas porque ZEP? (...) Com ZEP, você aumenta as desigualdades. Quando se escuta a palavra ZEP, todo mundo entende imediatamente (último ano do ensino médio, Epinay).

A conscientização dessa discrepância e o caráter manifesto de discriminação positiva dentro da linha das políticas de ZEP se opõem aos princípios de meritocracia e igualdade de oportunidades, ensinados aos alunos. Assim, estes questionam o próprio mérito: por que outros modos de seleção e avaliação, já que possuem as mesmas capacidades que os outros? E se não as possuem, por que adotá-los? A contradição é ainda mais dolorosa para os alunos mais envolvidos nos dispositivos que também são mais resistentes a qualquer infração ao modelo republicano. "As pessoas devem chegar lá por suas qualidades, suas capacidades, mesmo se for preciso lutar", insiste um aluno de último ano do ensino médio em Epinay. Em Bondy, uma aluna que ingressará finalmente em Sciences Po afirma preferir "limpar os banheiros do McDonald's com escova de dentes" ao invés de ser contratada para uma vaga de executiva a partir de cotas por ser árabe. Por que eu não sou somente isso, sou uma cidadã!" (último ano do ensino médio, Bondy). 
Assim, e ajudados pelo embalo midiático, os alunos se perguntam sobre os verdadeiros fundamentos destas ações: na realidade, trata-se de pegar os melhores, propiciar oportunidades para todos, fazer propaganda às suas custas ou, ainda, socializar os "jovens do subúrbio"? Alguns aspectos velados, além daqueles estritamente escolares do exame oral de admissão aos $\mathrm{CEP}^{21}$, reforçam as dúvidas. Aliás, as expectativas do júri, em termos de perfil e de personalidade, alimentam uma verdadeira preocupação do "casting". Emilie, hoje em Sciences Po, conta sua surpresa por ter sido escolhida, enquanto que avaliava negativamente seu desempenho oral do ponto de vista do conteúdo. Ela justifica seu sucesso mais por sua "vivacidade e espontaneidade". Em Clichy-sous-Bois, o aluno se preocupa se seus gostos musicais, pouco influenciados pelo subúrbio, não correspondem às expectativas identitárias do júri. Qual critério social predomina: ser "nascido da imigração" ou ainda vir do "distrito 93"? "Normalmente quando eles têm interesse em nós é para saber das nossas capacidades e não verdadeiramente da nossa cor", afirma este aluno do 20 ano do ensino médio em Clichy. Entretanto, como indica este "normalmente", isto é longe de ser uma certeza para os estudantes.

Assim, ao participarem dos programas, especificamente dos CEP, são desvendados por parte, os mecanismos de um sistema que, segundo explicações dadas, não é no fundo tão meritocrático. Eles percebem a arbitrariedade dos requisitos de seleção no ensino superior, além das desigualdades sociais mais profundas nas quais são apoiados.

Para nós, as informações passam por isso: biblioteca, livros, jornais. Mas para eles as informações podem passar pelos pais, a família... os vizinhos ou sei lá (...). Nós temos que arranjar os meios, enquanto pra eles é natural ( $2^{\circ}$ ano do ensino médio, Clichy).

Entre eles, os que conseguirão ingressar em Sciences Po serão levados a experimentar uma verdadeira "defasagem" contra a qual, retroativamente, "a motivação" parece bem frágil:

Frequentando as oficinas, na verdade, eu me dei conta, de que existia uma defasagem fora do comum. Quando cheguei a Sciences Po ficou ainda mais palpável, conversando com aquele pessoal! É isso que acaba comigo (...). Estou realmente fora daquela luta de classes. O que me irrita é que... é isso, somos jogados finalmente na mesma fossa, sem começar todos com as mesmas oportunidades. (...) Para meus pais, fazer Sciences Po é finalmente extraordinário, já para outros pais, é... apenas 
normal, como ir comprar pão. Para mim, é o negócio que me deixa mais frustrado (...). Fico com raiva, você não imagina (garota, 1ํano de Sciences Po, antiga aluna de Bondy, entrou pelo CEP).

Por outro lado, os dispositivos fazem ressaltar as desigualdades internas nos estabelecimentos de ensino. A visibilidade dos programas e o caráter excepcional dos meios empregados tornam ainda mais amargo o fato de que não são aproveitados por todos os alunos. Principalmente, algumas sessões tecnológicas e profissionais, menos reconhecidas simbolicamente e mais precárias, não são muito representadas nos programas, reforçando ainda as segmentações escolares tradicionais. Ao invocar esta violência social, vários alunos, sem criticar abertamente os dispositivos, apenas permanecem afastados ${ }^{22}$. Como frisa essa aluna de 2 a ano de ensino médio em Clichy a respeito do CEP: "Acho isso muito bom, mas realmente... não entro nesse lance." "Essa não é a minha", responde ela laconicamente, quando alguém tenta questioná-la mais detalhadamente. Alunos médios constatam as falhas de um sistema escolar restrito a sempre ajudar, segundo eles, àqueles que se saem melhor. Assim em Clichy, ao contrário do que foi prometido, os participantes das oficinas de preparação ao CEP foram selecionados a partir dos resultados no colégio. ${ }^{23} \mathrm{Em}$ Bondy, após análise dos boletins escolares, os alunos ganharam uma viagem para Boston. Disto, extraem uma visão "mesclada" ( 2 - ano do ensino médio, Bondy) da igualdade de oportunidades.

Não é porque resolvemos estudar que somos obrigatoriamente superdotados: podemos ter um nível mais baixo e, mesmo assim, sermos motivados. Então, eu acho que precisaria deixar uma oportunidade para aqueles que têm resultados não tão bons; talvez isso os estimulasse a se

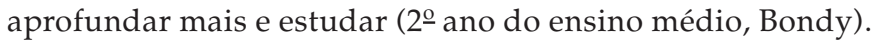

Impressão igual em Clichy, em alunas do 2o ano do ensino médio, que dizem acreditar apenas "pela metade" na igualdade de oportunidades. Concluem de modo muito expressivo: "Os professores, o colégio, enfim, vão tentar empurrar para frente os bons, você pode ir longe! Já os médios, serão apenas amparados... Enfim, para que se mantenham de pé e não caiam" (2o ano do ensino médio, Clichy).

Diante de dispositivos que reproduzem parcialmente a violência social dos julgamentos escolares, esses alunos, que se autodenominam de "médios", opõem o desejo de uma escola mais igualitária, que não se limite a ajudar os melhores, mas que verdadeiramente ofereça estímulos 
e oportunidades a todos. Trata-se de uma exigência de igualdade ${ }^{24} \mathrm{e}$ não apenas de meritocracia.

\section{CONCLUSÃO}

A forte ascensão do tema da diversificação das elites no âmbito político encontrou prolongamentos nas ações empreendidas por várias Escolas Superiores para ampliar a seleção e/ou implantar vias derrogatórias na admissão. A determinação do alvo se efetua segundo uma lógica socioterritorial especialmente desenvolvida na França e encontrada, por exemplo, na política da cidade. Esta lógica não visa intervir diretamente em indivíduos, mas em áreas desfavorecidas e classificadas como ZEP. Essa abordagem territorial tende a reforçar a visão homogênea de seu perfil social e escolar, considerando que os frutos dos programas instalados serão aproveitados pelo maior número através de um tipo de "requalificação escolar" difusa em termos de resultados, mas também de imagens e atratividade. Paralelamente às ações escolares e pedagógicas realizadas junto aos alunos com o objetivo de prepará-los para o ingresso em Sciences Po (oficina CEP), trata-se na realidade de lutar contra uma estigmatização progressiva desses colégios, reduzindo assim o evitamento. Esses efeitos, difíceis de avaliar, necessitam de um aparelhamento metodológico problemático a ser elaborado no atual contexto, a fim de medir os efeitos da interferência de Sciences Po no êxito escolar (taxa de sucesso no vestibular de admissão em Sciences Po ou para outros canais seletivos do ensino superior, menções etc.) e na seleção (evolução do perfil, evitamento etc.).

Entretanto, no que diz respeito aos efeitos da percepção da meritocracia e das desigualdades pelos pais e alunos, as linhas de divisão evidenciadas nesse artigo tendem a diluir-se tanto pela inovação quanto pelo alcance deste programa, num contexto mais amplo, em que o tema da diversidade e da luta contra as discriminações rejeita, no segundo plano, o tema mais clássico da luta contra as desigualdades (Michaels, 2009; Oberti, 2007). De fato, o resultado mais visível e midiático é o ingresso em Sciences Po de alunos que nunca poderiam ter passado, sem este dispositivo, às portas da rue Saint Guillaume*. Porém, o risco é manter um "elitismo republicano" baseado numa marcante distinção entre os canais de elite e o resto, isto é, continuar a garantir alto desempenho escolar para um pequeno número (um pouco mais diversi-

* [N. E. Endereço de Sciences Po, em Paris.] 
ficado, é verdade), sem necessariamente conceder meios para elevar o nível escolar da massa. Por outro lado, as pesquisas PISA mostram que os países mais igualitários em termos escolares também são aqueles que têm desempenhos mais elevados. Levantar o nível escolar do maior número de alunos não resulta numa baixa de nível da elite (Baudelot e Establet, 2009).

Nos dois casos (CEP ou programa experimental), a questão do perfil dos alunos que tirarão proveito destes dispositivos não deve ser eliminada e remete à questão dos limites de um nicho territorial (limitado a um número restrito de estabelecimentos). Por um lado, mesmo que esses estabelecimentos acolham uma maioria de alunos provenientes de meios populares e desfavorecidos, outras categorias sociais mais favorecidas e graduadas também escolarizam os filhos e se apropriam mais facilmente desse tipo de medidas. Os acessos à informação e à compreensão dos programas constituem vetores fundamentais de desigualdades cuja inércia global é difícil de avaliar. A convenção ZEP de Sciences Po, então concentrada nesses únicos colégios, consegue selecionar num amplo espectro de categorias sociais. Em 2010, entre os estudantes que entraram em Sciences Po por CEP, cerca de $20 \%$ vêm de categorias sociais intermediárias e, na mesma proporção, de categorias sociais superiores (Tiberj, 2011). Apenas os filhos de profissões intermediárias representam, por exemplo, $14 \%$ dos admitidos por essa via. Nota-se também que no conjunto dos estudantes de Sciences Po, graças a esta medida, seu peso que tendia a diminuir ligeiramente entre 1987 e 1997 (de 8\% a 7\%) aumentou ao longo da última década para atingir 10\% em 2011. Como comparação, os filhos de operários passaram no mesmo período de 1 a $4,5 \%$ e os filhos de funcionários em geral, de $2 \%$ a $7,5 \%$. Assim, sem o CEP, a parte dos estudantes oriundos de classes superiores teria passado de $70 \%$ a $77 \%$ e a parte advinda das categorias populares teria diminuído de 12,5\% a 7\% (Tiberj, 2011). Desse ponto de vista, não pode ser negado o efeito significativo do CEP, não somente em termos de democratização de acesso a essa Escola Superior (mais jovens provenientes das classes populares a frequentam), mas também de diversificação social ${ }^{25}$ (uma vez que se aproveitam igualmente os jovens de categorias intermediárias). Antes de tudo, isso cria implicitamente uma situação delicada para os colégios comuns, nem prestigiosos, nem desfavorecidos, nos quais a presença da classe média baixa e das classes populares é significativa. Esses alunos, globalmente pouco representados nos canais mais seletivos do ensino superior, permanecem à distância de uma política territorial de "diver- 
sificação da elite". Aliás, é impressionante ver até que ponto os próprios alunos dos colégios conveniados e experimentais veem nisso uma situação injusta.

A questão da "diversificação da elite" deixa também de lado o lugar dado aos critérios étnicos. A confusão e o eufemismo dominam nas declarações e documentos que se referem à noção de diversidade. $\mathrm{O}$ fato de ser um alvo territorial alimenta esse equívoco e esse desvio de toda categorização étnico-racial ou étnico-cultural, enquanto, implicitamente, essa dimensão é envolvida. Já sobre a relação com a escola, a imbricação entre o nível social, o nível de educação e a origem estrangeira é complexa e obriga a nunca considerar uma ou outra independentemente das outras. Será preciso encarar esse impasse metodológico e político, e os próprios alunos se questionam sobre a concepção da diversidade e da discriminação subjacente: social ou étnica, ou mistura das duas. A participação dos alunos nos programas os leva a dar mais importância às desigualdades socioeconômicas. Se a aproximação pela diversidade lhes parece legítima, eles a consideram redutora e incapaz, por si mesma, de lutar eficazmente contra estas desigualdades.

É preciso insistir sobre o efeito paradoxal mais que perverso - apesar de não esperado nem desejado - da presença de uma Escola Superior, Sciences Po no caso, nesse tipo de estabelecimento de ensino. Se, por um lado, a crença meritocrática na Escola Superior, amplamente mobilizada pelos professores mais envolvidos, reforçada particularmente junto aos alunos que fazem as oficinas CEP; por outro lado, essa presença contribui para mudar sua visão das desigualdades. A grande mobilização dos professores é muito apreciada pelos alunos, que em troca se projetam num modelo de envolvimento e sucesso do qual esperam resultados e sabem que o mesmo é apreciado pelos próprios professores. As duas partes são legitimadas e firmadas na importância do compromisso e a referência ao paradigma doação/não doação reveste-se de todo sentido. Também, entende-se melhor a dureza da prova quando esta acaba num fracasso. Porém o efeito inesperado, particularmente identificável nas entrevistas coletivas com os alunos, leva à visibilidade ampliada das desigualdades, como se esses programas veiculassem para "dentro dos muros" do estabelecimento, uma realidade que permanecia essencialmente fora. Isso é diretamente ligado ao tamanho do trabalho de "reparação" e às diversas "pedagogias na nova segurança e proteção" dos quais os alunos tinham consciência, porém subestimavam os pressupostos e os motivos no contexto esco- 
lar. O trabalho de "reparação" revela principalmente a distância com outros colégios e vai ao encontro da ideia que expressam por estar num colégio como os outros. Essa tensão fundamenta a experiência colegial, impregnada por uma "crença necessária" na meritocracia ("ficção necessária", "desigualdade justa"), dentro de um programa que lhes indica que as cartas desse jogo são ainda mais marcadas do que eles imaginavam. Para quem não participa desses programas, essa presença consolida o isolamento dos mundos sociais e escolares e também dos princípios já bastante manifestos de hierarquização interna entre alunos.

(Recebido para publicação em fevereiro de 2012)

(Reapresentado em novembro de 2012)

(Aprovado para publicação em janeiro de 2013)

\section{NOTAS}

1. Trataremos aqui apenas dos alunos de ensino médio. Para uma análise que leve em conta igualmente a relação com a escola dos pais, ver Oberti, Sanselme e Voisin (1999).

2. Essa noção reenvia aqui à definição dada por François Dubet (1994), bem distinta daquela normalmente usada no jargão sociológico e administrativo em vigor atualmente.

3. Esses dados são confirmados por estimações baseadas nos primeiros nomes dos alunos dos colégios envolvidos. Ver Felouzis (2003) e Lagrange (2006) para exemplos mais desenvolvidos deste método. Segundo este método, 22\% dos alunos do Lycée Nobel de Clichy-sous-Bois e 28,7\% do Lycée Feder de Epinay-sur-Seine têm uma origem francesa metropolitana ou europeia. A congruência destes resultados com os da pesquisa impressiona e mostra nos dois casos uma concentração muito forte de alunos dos quais a França metropolitana não é o país de origem.

4. Trata-se do prefixo do distrito de Seine-Saint-Denis, normalmente usado pelos jovens para indicar e reforçar o fato de pertencer a este território emblemático da cultura dos conjuntos habitacionais e do subúrbio.

5. Essa imagem deu origem à seleção dos estabelecimentos de ensino (colégios "ZEP" de Seine-Saint-Denis) e, portanto, a presença dos dispositivos. O Colégio de Clichy-sous-Bois foi, aliás, escolhido por causa dos distúrbios de rua.

6. A pesquisa conduzida para a Halde sobre a flexibilização do mapa escolar mostra como essa política vem finalmente reforçar o sentimento de enclausuramento, segregação e injustiça das famílias e parentes. Ver Oberti, Préteceille e Rivière (2011). 
7. Sobre as ambições escolares elevadas dos pais imigrantes, ver Beaud (2002), Brinbaum e Kieffer (2005) e Caille (2007). Essa constatação se encontra também nos questionários e nas entrevistas que realizamos junto aos pais.

8. Os alunos de ensino médio se queixam particularmente da maneira empregada pelos orientadores escolares, denominados "desorientadores" que os encaminham para os canais profissionais e tecnológicos, canais de ensino desvalorizado no sistema francês. Sobre os rumos da orientação escolar, ver Caille (2005) e HCE (2008).

9. Dubet (1991) mostrou como essa "motivação" difícil e abstrata é o cerne da experiência dos "novos alunos", alunos de classe média contemporâneos da massificação do ensino médio. A motivação é aqui ainda mais frágil e indispensável nesses ambientes urbanos escolares desvalorizados.

10. Testemunha disso são os discursos mágicos e fatalistas dos alunos sobre a motivação ("isso poderia levar bem longe, mas estou sem vontade", $2 \underline{0}$ ano do ensino médio, Clichy), como se ela fosse totalmente externa a eles.

11. O que multiplica o crédito de confiança dos pais na Escola Superior e em seus filhos. (Oberti, Sanselme e Voisin, 2009).

12. Também é nesse contexto que os efeitos de supervisão ou "efeitos provenientes do mestre" são mais importantes (Bressoux, 1994).

13. Também para seus pais, testemunhas do incipiente trabalho de informação junto às famílias durante a implementação dos dispositivos, ao oposto dos discursos sobre o necessário envolvimento das mesmas.

14. Uma literatura sobre as difíceis consequências de uma pedagogia aberta para alunos oriundos dos meios populares. Bautier e Rochex (1998) mostraram bem as dificuldades dos "novos alunos" presos numa "lógica institucional de encaminhamento": os saberes não lhes parecem distintos dos exercícios onde foram adquiridos, enquanto estes são encarados como uma sequência de tarefas heterogêneas a serem realizadas para passar de ano e se projetar até o vestibular. Eles custam a dar sentido aos saberes. A passagem a uma "lógica cultural de aprendizagem e desenvolvimento", chave do sucesso escolar, não é dada de antemão e exige um trabalho específico dirigido às aprendizagens.

15. A importância do sentimento de proteção oferecido pelo estabelecimento de ensino se destaca nitidamente na fala de uma jovem do Lycée de Epinay-sur-Seine, depois do ingresso em Sciences Po. Ela opõe o caráter de convívio até amistoso e tranquilizador do colégio na relação com os professores, aocaráter competitivo e individualista de Sciences Po. Ela justifica a depressão no meio do primeiro ano, porque ficou "de saco cheio do ambiente e da falta de convívio"; encontrará refúgio na casa da avó e repetirá o primeiro ano.

16. Mais distante da ideia de aumentar o potencial social desses alunos para lhes permitir construir projetos pessoais de qualidade, dirigidos para o próprio meio social, como na lógica de empowerment nos Estados Unidos (Baquet, 2005).

17. Os alunos manifestam, às vezes surpreendentemente, uma grande consciência da força transformadora de ascensão social, tal como essa aluna do último ano do ensino médio em Epinay: "Eu sou mais do lado socialista, ainda não tenho ideias definitivas. Isso depende também da posição ocupada. Se eu me tornar executiva, talvez eu opte mais para a direita". 


\section{Marco Oberti e Agathe Voisin}

18. Sobre o sentimento de traição ligado à experiência da mobilidade social forte e ascendente, ver Naudet (2010).

19. Sobre a construção pela Escola das famílias imigrantes como problemáticas, ver Payet (1995).

20. No sentido da "cultura da reticência", mencionada por Rayou (1998). "Cultura da reticência" que leva os alunos através de certa "autorretenção" de um "no que me diz respeito", a minimizar o domínio do colégio sobre eles e sobre as relações com os outros, "distinguindo cuidadosamente o aluno que se tem obrigação de ser, da pessoa de quem desejam preservar a autonomia".

21. A prova oral de admissão é, em parte, uma prova de avaliação de personalidade, que enfoca a curiosidade e abertura de espírito. É "uma prova de reflexão e de personalidade, e não visa a desestabilizar o candidato. Possibilita valorizar qualidades como reflexão, argumentação e curiosidade intelectual". "Trata-se, para o candidato, de apresentar suas motivações (o site destaca essa frase) e seu projeto de estudo, manifestando abertura de espírito, espírito crítico e capacidade de análise". http://www.sciences.po.fr/formation/inscriptions/cep.html\#7; http://admissions.sciences-po.fr/fr/node/ 81

22. Numa lógica muito próxima da philia colegial descrita por Rayou (1998), porque o que os alunos criticam nos dispositivos é de se esfacelar a comunidade colegial hierarquizando-a.

23. Para poder ingressar no $2 \underline{\underline{O}}$ ano do ensino médio na Associação "Réussir aujourd'hui" ("Ter sucesso hoje"), os alunos deveriam ter recebido menção honrosa ao final do ano anterior.

24. Esse princípio de igualdade que demanda dar mais àqueles que têm menos, é um dos quatro princípios de justiça na Escola Superior identificados por Dubet e Duru-Bellat (2004). Os três outros são a igualdade de oportunidade meritocrática; o princípio mínimo de competência e saberes garantidos; e finalmente, a independência das "esferas de justiça" entre a Escola e a sociedade.

25. Esse ponto não é necessariamente percebido como negativo e pode integrar um objetivo de manutenção da mixidade social nos estabelecimentos conveniados. Podemos formular a hipótese de que, se esse programa não envolvesse apenas os filhos das classes populares desses estabelecimentos, esses colégios seriam menos atrativos para os filhos das classes médias e superiores, já pouco numerosas, e que aí notariam uma dupla desvantagem. 


\section{REFERÊNCIAS BIBLIOGRÁFICAS}

BACQUE, Marie-Hélène. (2005), “Associations 'Communautaires' et Gestion de la Pauvreté. Les Community Development Corporations à Boston". Actes de la Recherche en Sciences Sociales, no 160, pp. 46-65.

BARRERE, Anne e MARTUCCELLI, Danilo. (1998), “La Citoyenneté à l'École: Vers la Définition d'une Problématique Sociologique". Revue Française de Sociologie, vol. 39, no 4, pp. 651-671.

BAUDELOT Christian e ESTABLET Roger. (2009), L'Élitisme Républicain. L'École Française à l'Épreuve des Comparaisons Internationales. Paris, Le Seuil, La République des Idées.

BAUTIER, Elizabeth e ROCHEX, Jean-Yves. (1998), L'Expérience Scolaire des “Nouveaux Lycéens", Démocratisation ou Massification? Paris, Armand Colin.

BEAUD, Stéphane. (2002), 80\% au Bac et Après? Les Enfants de la Démocratisation Scolaire. Paris, La Découverte.

BRESSOUX, Pascal. (1994), “Les Recherches sur les Effets-école et les Effets-maîtres”. Revue Française de Pédagogie, no 108, pp. 91-137.

BRINBAUM, Yaël e KIEFFER, Annick. (2005), “D’une Génération à l’ Autre, les Aspirations Éducatives des Familles Immigrées: Ambition et Persévérance". Éducation \& Formations, no 72, pp. 53-75.

CAILLE, Jean-Pierre. (2005), “Le Vécu des Phases d'Orientation en Fin de Troisième et de Seconde". Éducation \& Formations, no 72, pp. 81.

. (2007), “Perception du Système Éducatif et Projets d'Avenir des Enfants d'Immigrés". Éducation et Formations, no 74.

DUBET, François. (1991), Les Lycéens. Paris, Seuil.

(1994), Sociologie de l'Expérience. Paris, Seuil.

(2002), Le déclin de l'Institution. Paris, Seuil.

. (2007), L'Expérience Sociologique. Paris, La Découverte.

e DURU-BELLAT, Marie. (2004), “Qu'est-ce qu'une École Juste?”. Revue Française de Pédagogie, no 146, pp. 105-114.

FELOUZIS, Georges. (2003), "La Ségrégation Ethnique au Collège et ses Conséquences”. Revue Française de Sociologie, vol. 44, no 3, pp. 413-447.

HAUT CONSEIL de L'EDUCATION. (2008), “L'Orientation Scolaire. Bilan des Résultats de l'École - 2008". Paris, Haut Conseil de l'Education.

JELLAB, Aziz. (2005), “Les Enseignants de Lycée Professionnel et leurs Pratiques Pédagogiques: Entre Lutte contre l'Échec Scolaire et Mobilisation des Élèves". Revue Française de Sociologie, vol. 46, no 2, pp. 295-323.

LAGRANGE, Hughes. (2006), “'Ethnicité' et Déséquilibres Sociaux en Île-de-France'”, in H. Lagrange (ed.), L'Épreuve des Inégalités. Paris, PUF.

MICHAELS, Walter Ben. (2009), La Diversité contre l'Égalité. Paris, Liber. 


\section{Marco Oberti e Agathe Voisin}

NAUDET Jules. (2010), Analyse Comparée de l'Expérience de la Mobilité Sociale Ascendant Intergénérationelle aux États-Unis, en France et en Inde. Tese de doutorado em sociologia, Sciences Po, Paris.

OBERTI, Marco. (2007), L'Ecole dans la Ville. Paris, Presses de Sciences Po.

, PRÉTECEILLE Edmond e RIVIÈRE, Clément. (2011), Les Effets de l'Assouplissement de la Carte Scolaire dans la Banlieue Parisienne. Rapport intermédiaire HALDE/DEPP. Paris, Sciences Po-OSC.

OBERTI, Marco, SANSELME, Franck e VOISIN, Agathe. (2009), "Ce que Sciences Po Fait aux Lycéens et à leurs Parents: Entre Méritocratie et Perception d'Inégalités". Actes de la Recherche en Sciences Sociales, no 180, pp. 102-124.

PAYET, Jean-Paul. (1995), Collèges de Banlieue. Ethnographie d'un Monde Scolaire. Paris, Armand Colin.

PRETECEILLE, Edmond. (2006), “La Ségrégation Sociale a-t-elle Augmenté? La Métropole Parisienne entre Polarisation et Mixité". Sociétés Contemporaines, no 62, pp. 69-93.

. (2009), "La Ségrégation Ethno-raciale dans la Métropole Parisienne". Revue Française de Sociologie, vol. 50, no 3, pp. 489-519.

RAYOU, Patrick. (1998), La Cité des Lycéens. Paris, L'Harmattan, Débats/Jeunesses.

TIBERJ, Vincent. (2011), Sciences Po, dix ans après les Conventions Education Prioritaire. Paris, Sciences Po, Centre d'Etudes Européennes.

VAN ZANTEN, Agnès. (2001), L'École de la Périphérie. Scolarité et Ségrégation en Banlieue. Paris, PUF.

VITIELLO, Audric. (2008), "L'Éducation à la Citoyenneté". Raisons Politiques, no 29, pp. 169-187. 


\begin{abstract}
The High School Students and Sciences Po: Between the Meritocracy and the Perception of Inequality

Several "grandes écoles" develop programs targeting inner city high schools in order to diversify their recruitment and, more generally, incentivize some students to reevaluate positively their educational ambitions. The impact of these programs cannot be reduced to their mere efficiency in terms of affirmative action. Indeed, the active presence of a grande école in stigmatized urban and educational environments transforms the way students relate to schools by redefining their perception of meritocracy inequalities and discriminations. By analyzing Sciences Po programs in four high schools of the Seine-Saint-Denis, this article intends to shed some light on the way an unprecedented educational offer is perceived, and on the tensions generated by the emergence of educational and social aspirations associated with an acute perception of inequalities.
\end{abstract}

Key words: inequalities; education; segregation; Sciences Po

\title{
RÉSUMÉ
}

Les Lycéens face à Sciences Po: Entre Méritocratie et Perception d'Inégalités

Plusieurs grandes écoles développent des programmes dans les lycées défavorisés afin de diversifier leur recrutement et, plus largement, d'inciter une partie des élèves à revoir leurs ambitions scolaires à la hausse. Les effets de tels programmes ne peuvent se réduire à leur seule efficacité en termes de "discrimination positive". En effet, la présence et les actions d'une grande école dans des environnements scolaires et urbains stigmatisés agissent sur le rapport à l'école des élèves, en contribuant à redéfinir leur perception de la méritocratie, des inégalités et des discriminations. A travers l'étude des programmes Sciences Po dans quatre lycées de la Seine-Saint-Denis, cet article se propose d'éclairer les mécanismes de réception d'une offre scolaire inédite, ainsi que les tensions qui naissent d'une montée des aspirations scolaires et sociales couplée à une perception plus aiguë des inégalités.

Mots-clés: inégalités; éducation; ségrégation; Sciences Po 